DOI: https://doi.org/ 10.25100/iyc.v20i2.5240

INGENIERÍA DE MATERIALES

\title{
Caracterización mecánica de recubrimientos de aluminio-silicio depositados por CVD-FBR sobre el acero inoxidable AISI 316 y oxidado en vapor de agua
}

\section{Mechanical characterization of aluminum-silicon coating deposited by CVD-FBR on austenitic stainless steel AISI 316 and vapor oxidation}

\author{
Diego Pérez Muñoz ${ }^{1}$, José Luddey Marulanda Arévalo ${ }^{1}$, Carlos Mauricio Moreno Tellez² \\ ${ }^{1}$ Grupo de Investigación en Materiales Avanzados GIMAV. Universidad Tecnológica de Pereira. Pereira-Colombia, \\ ${ }^{2}$ Instituto para la investigación y la innovación en ciencia y tecnología de materiales. \\ Universidad Pedagógica y Tecnológica de Colombia. Tunja-Colombia, \\ dperez@utp.edu.co,jlmarulanda@utp.edu.co,carlosmauricio.moreno@uptc.edu.co
}

(Recibido: 1 de septiembre de 2017 - Aceptado: 8 de junio de 2018)

\section{Resumen}

El recubrimiento de Aluminio-Silicio fue depositado a $540^{\circ} \mathrm{C}$ sobre el acero austenítico AISI 316 por deposición química de vapor en lecho fluidizado (CVD-FBR), para luego ser tratado a $750{ }^{\circ} \mathrm{C}$ en argón por 2 horas. Las muestras de estudio fueron oxidadas en un loop de vapor a $750{ }^{\circ} \mathrm{C}$, los cuales presentaron una disminución en la velocidad de corrosión a altas temperaturas con respecto a las muestras no recubiertas (más de 100 veces). Estudios de Microdureza y Nanoindentación fueron realizados con el fin de evaluar los beneficios del recubrimiento de Al-Si por CVD-FBR, encontrando un incremento en la dureza del recubrimiento con respecto al sustrato. Adicionalmente, Microscopía Electrónica de Barrido (SEM) fue llevada a cabo para caracterizar los cambios en la microestructura de las muestras oxidadas. La sección transversal de las muestras fue sometida a Microscopía de Fuerza Atómica (AFM), enfocándose en el espesor del recubrimiento (cambios topográficos, gradiente de rugosidad y posibles fases formadas). Los resultados AFM verificaron una correlación entre la dureza y los perfiles de voltaje encontrados durante los barridos.

Palabras clave: Deposición química de vapor por lecho fluidizado (CVD-FBR); Recubrimiento; Oxidación en vapor de agua; Corrosión; Dureza; Nanoindentación.

\begin{abstract}
Aluminum-Silicon Al-Si coating deposited at $540{ }^{\circ} \mathrm{C}$ on the austenitic stainless steel AISI 316 by chemical vapor deposition in fluidized bed reactor (FBR-CVD), afterwards samples were thermally treated at $750{ }^{\circ} \mathrm{C}$ under argon for 2 hours. The coated samples were oxidized in water vapor loop at $750{ }^{\circ} \mathrm{C}$, which showed a decrease in the corrosion rate at high temperatures in respect with the oxidized uncoated substrate (more than 100 times). Microhardness and nanoindentation studies were performed in order to assess the benefits of the Al-Si coating by CVD-FBR, finding an increase in the coating hardness with respect to the substrate. Additionally Scanning Electron Microscopy (SEM) was carried out to characterize micro-structural changes of the oxidized samples. Cross-section samples were subjected to Atomic Force Microscopy (AFM) focusing on the thickness of coating (topographical changes, roughness gradient and possible formed phases). Results of AFM verified a correlation between hardness and voltages profiles found during scanning.
\end{abstract}

Keywords: Chemical Vapor Deposition by Fluidized Bed (CVD - FBR); Coatings; Vapor oxidation; Corrosion; Hardness; Nanoindentation. 


\section{Introduction}

The industrial growth has generated the research of alternative process, as well as new tools and materials, due to the market faces to changing requirements. The industry uses coatings to protect materials used in machinery construction and devises, extending their service life and reducing maintenance cost and production. The main objective of coatings is give extra properties to materials, which improve their chemical and mechanical characteristics, such as hardness, thermal protection, wear resistance and corrosion resistance, among others. Therefore, to know the mechanical properties of protectives coatings has become an essential part to materials characterization, in order to develop in many way the substrate ${ }^{(1-3)}$.

The ability of endure corrosion is attributed to the formation of dense oxide chromium layer formation and its slow growth. However, the water vapor in the air or oxygen can have a not good effect in the stainless steels oxidation inducing it to the catastrophic oxidation, due to the formation of not-protective oxide layer rich in iron, reducing the performance and service life of iron. The oxidation by water vapor has highly importance in materials selection for electric energy generation by vapor turbines, since in thermal plants many components are exposed to the water vapor at high temperature ${ }^{(4-6)}$.

The advantages of chemical vapor deposition technique by fluidized bed are in the combination of the thermal activation and fluidized bed, which has as result the increase of the heat and mass transfer among the fluidized bed, gas and samples, obtaining a great stability of the temperature and a homogenous mix of reactive gases and the fluidized particles; generating a high quality reaction in the bed. The foregoing phenomenon implies to have a surface treatment combining the adaptability with low operative costs ${ }^{(5,7)}$.

The study of mechanical, physical, chemical and structural properties are some of main characteristics for carry out the correct mechanical characterization of any material. At present, one topic of great interest about materials characterization is the relationship between the material structure and its properties, always seeking the correct operation of tool or devise. One studied method to understand the relationship above mentioned is explore the possible connections between the structure and the material functionality at micrometric scale, focused the interest in mechanic-elastic properties. Specifically for the materials studied in this research, the coatings reached few micrometers (about $20 \mu \mathrm{m}-30 \mu \mathrm{m}$ ), thus, the study migrated to the Atomic Force Microscopy (AFM) [8-11]. The good behavior of Al-Si coating front the water vapor oxidation leaded into necessity to evaluate its mechanical properties, projecting into industrial applications in the future.

The hardness Vickers is based in the materials resistance against a penetration of a diamond pyramidal tip with square base and an angle of $130^{\circ}$ between faces, and later analyzing the sample behavior under load selected. As others methods of hardness measure, this one uses an indentator, printing a footprint on the study sample ${ }^{(12,13)}$.

Advanced indentation techniques have been highly applied to characterize the behavior of a lot variety of materials at scales as small as the nanoscale. Recently, the nanoindentation tests have been extended to study the mechanical properties of coatings deposited on conventional iron substrates, seeking improve them from superficial properties. The nanoindentation is an ideal technique to know the nano-hardness and the elasticity module of coatings deposited by CVD-FBR, due to its results are based in the Oliver \& Pharr method ${ }^{(14,16)}$.

\section{Metodologhy}

This research is about the mechanical properties evaluation by means of Microhardness and nanoindentation on aluminum-silicon coatings deposited by CVD-FBR on austenitic stainless steel AISI 316. Study samples $(20 \mathrm{~mm} \times 6 \mathrm{~mm} \times 2 \mathrm{~mm})$, were sanded by emery paper from $\mathrm{N}^{\circ} 100$ to $\mathrm{N}^{\circ}$ 600 , later samples were cleaned during 10 minutes in acetone by ultrasound. The deposition of Al-Si coatings by CVD-FBR was carried out under the 
following conditions: Atmospheric pressure, the fluidized bed was high purity powder of aluminum and silicon with $400 \mu \mathrm{m}$ particle size; as inert bed was used alumina powder $\left(\mathrm{Al}_{2} \mathrm{O}_{3}\right)$. Argon was used as inert gas for the fluidization mix ( $\mathrm{Ar}$ 99,999\%), hydrogen chloride as reactive gas ( $\mathrm{HCl} 99,999 \%)$ and as reductive gas hydrogen $\left(\mathrm{H}_{2}\right.$ de $\left.99,999 \%\right)$. The coatings were grown modifying the relation between active and neutral gases, the amount of aluminum and silicon on the bed and finally the deposition time. Deposition temperature was $540^{\circ} \mathrm{C}$ with active gases relation of $\mathrm{HCI} / \mathrm{H}_{2}: 1 / 15,3$; with a bed $2.5 \mathrm{~g}$ of aluminum and $7.5 \mathrm{~g}$ of silicon and the gases relation of $50 \%$ actives and $50 \%$ neutral during 1 hour. Late samples were subjected to thermal treatment $\left(750^{\circ} \mathrm{C}, 2\right.$ hours, Ar atmosphere); lastly, samples were oxidized in a closed water vapor loop at $750^{\circ} \mathrm{C}$ for 1000 hours. Samples were analyzed by Scanning Electron Microscopy (SEM) with a JEOL Mod. JM-6400. Microhardness was carried out by indentation Vickers test following ASTM E384 standard using a Wilson Wolper micro durometer with a $220 \mathrm{~N}$ load and the results were studied by the software IBIS (Instrumented Indentation Analysis Software) [17]. After analysis were done in different laboratories, the results were compared among three zones: coating, coating-substrate and substrate. Five indentation groups were done in every zone of the across section sample, as shown in figure 1, in order to plot microhardness behavior across sample.

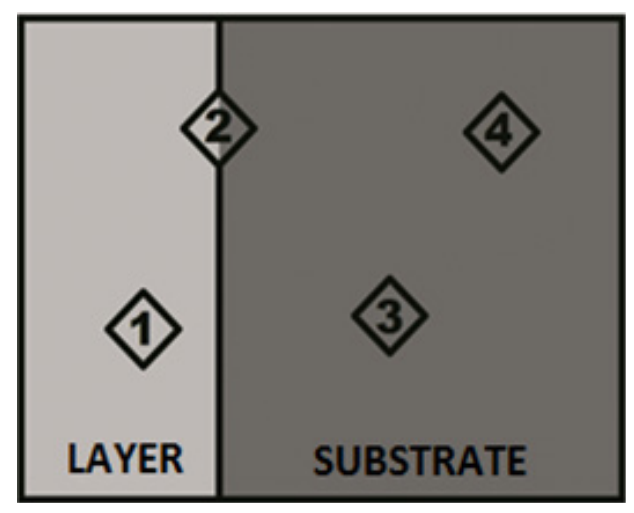

Figure 1. Selected zones for micro hardness test

On the other hand, equipment Nanosurf with Easyscan 2 software and a controller C3000 car- ried out the tests of Atomic Force Microscopy AFM, in addition the images process was done by SPIP 6.2.6 software [18-20]. The sweep direction of AFM test was from left to right, start on coating $(\mathrm{C})$, followed by the coating/substrate zone (C-S) and finally the substrate (S). The AFM measurements let to know the deposition coating condition on the substrate, reporting thickness in a range $10 \mu \mathrm{m}$ y $15 \mu \mathrm{m}$, as well as was observed continuity on the interphase (C-S), which shows information about good adherence of coating, without ignoring the properties variations due to oxidation. Obtained data by AFM are depending variables and they are function of kind of material, thermal treatment and oxidation on samples.

In addition, Ibis Authority from Fischer Cripps Labs carried out nano-indentation tests. The nano-indentator was used in a closed loop method; with load-download cycles, with 5 seconds for maximum load and 15 seconds for minimum load The thermal variation was considered and the possible creep effects. For maximum load was used $1 \mathrm{mN}$, making the plot of nano-hardness profiles with about $20 \mu \mathrm{m}$ from coating to substrate, with $2 \mu \mathrm{m}$ steps close to interphase (C-S) and $15 \mu \mathrm{m}$ on the substrate. The produced diffusion by oxidation process on coatings materials, as well as substrates, produce important changes in the chemical and mechanical properties ${ }^{(2,5,6)}$. On this basis, to know the hardness at micro and nano scale will drive the future researching and they will provide relevant information about improvements in surface engineering area. The equipment was previously calibrated and the results was analyzed by Oliver \& Pharr method ${ }^{(19-21)}$, using a four faces pyramidal nano-indentator. Investigations of Al-Si coatings, as well as $\mathrm{Al}$ coatings, reported these can increase up to 100 times the resistance against water vapor oxidation and this phenomenon led to the study of their mechanical properties ${ }^{(7-17)}$.

\section{Results and discussion}

In Table 1, the Vickers micro-hardness of the cross section of the aluminum coating are shown, where the hardness for samples with and without thermal treatment and oxidized samples in the 
steam loop at $750{ }^{\circ} \mathrm{C}$ during 400 and 1000 hours are detailed. It is observed that, as in past studies of aluminum coatings ${ }^{(26)}$, the highest micro-hardness are found in the coating-substrate interface (zone 2 of figure 1). The previous phenomenon happened due to the formation of aluminum-silicon inter-metals such as $\mathrm{FeAl}, \mathrm{FeAl}_{2}, \mathrm{Al}_{2} \mathrm{FeSi}$, $\mathrm{Cr}_{3} \mathrm{Si}, \mathrm{AlCrFe}_{2}, \mathrm{Al}_{5} \mathrm{FeNi}, \mathrm{Fe}_{2} \mathrm{Si}, \mathrm{Cr}_{3} \mathrm{Si}$ and $\mathrm{AlNi}$, according to the XRD analyzes performed in this investigation, but not provided here $(5,16,17)$. These inter-metallic ones are formed by the diffusion of the aluminum of the coating towards the substrate and the diffusion of the iron, chromium and nickel towards the surface during the thermal treatment and the oxidation process. This phenomenon was also witnessed in other investigations ${ }^{(2,5,6,22)}$.

Table 1. Vickers hardness of the cross section of the Al-Si coatings

\begin{tabular}{cccccc}
\hline & $\begin{array}{c}\text { With TT } \\
\mathbf{[ H V}] \\
{[\mathbf{2 3} \mathbf{~ g}]}\end{array}$ & $\begin{array}{c}\text { Without TT } \\
{[\mathbf{H V}][\mathbf{2 3} \mathbf{~ g}]}\end{array}$ & $\begin{array}{c}\text { Oxidized } \\
\mathbf{4 0 0} \mathbf{~ h} \\
{[\mathbf{H V}][\mathbf{2 3} \mathbf{~ g}]}\end{array}$ & $\begin{array}{c}\text { Oxidized } \\
\mathbf{1 0 0 0} \mathbf{~ h} \\
{[\mathbf{H V}][\mathbf{2 3} \mathbf{g}]}\end{array}$ & $\begin{array}{c}\text { Standard } \\
\text { deviation }\end{array}$ \\
\hline $\begin{array}{c}\text { Zone } \\
\mathbf{1}\end{array}$ & 198,35 & 204,98 & 190,17 & 186,47 & 8,31 \\
$\begin{array}{c}\text { Zone } \\
\mathbf{2}\end{array}$ & 414,43 & 415,92 & 380,10 & 377,25 & 21,11 \\
$\begin{array}{c}\text { Zone } \\
\mathbf{3}\end{array}$ & 173,53 & 175,95 & 166,14 & 162,44 & 6,30 \\
$\begin{array}{c}\text { Zone } \\
\mathbf{4}\end{array}$ & 170,68 & 169,07 & 158,79 & 157,67 & 6,93 \\
\hline
\end{tabular}

"Without TT", means without heat treatment and "With HT", with heat treatment

It is observed that the coating has a higher hardness compared to the substrate and is also uniform and has good adherence, as it during the entire study process there was no evidence of detachment; as also, in the interface coating-substrate was the area where the highest hardness was presented. Also, it could be said that in the aluminum-silicon coating the hardness in the external zone decreases because it does not have adequate support around the microhardness trace, because it has a size of approximately $9 \mu \mathrm{m}$ and the coating has a thickness approximately $20 \mu \mathrm{m}$, it is also noticeable that both on the coating and on the coating-substrate interface there is influence of the metallographic assembly in the measure of the hardness. On the other hand, the changes in the hardness of each of the zones for the samples with thermal treatment and without heat treatment show a minimum change in their values, unlike the hardness values of the same samples oxidized at 400 and 1000 hours. The decrease in the hardness values in the oxidized samples is related to the decrease of aluminum and the increase on surface iron generated by the inter-diffusion of these elements during oxidation process. Due to measures were taken on the cross section of samples, the print depth is not a limiting for measures, although, the substrate influences on micro-hardness, due to there is no suitable distance between measures (3 times the print size). Even so, the higher hardness values were obtained on the external sample zone.

In the figure 2 is observed the cross section of AlSi coatings on AISI 136 steel oxidized at $750^{\circ} \mathrm{C}$ during 1000 hours in a vapor loop, which has four zones. The most external zone, in black color, it is composed of $70 \%$ of aluminum, $13 \%$ of oxygen, $12 \%$ of iron and $5 \%$ of silicon. These elements formed layers such as $\mathrm{Al}_{2} \mathrm{O}_{3}, \mathrm{FeCr}_{2} \mathrm{O}_{4}$, $\mathrm{Fe}_{2.45} \mathrm{Si}_{0.55} \mathrm{O}_{4}$ y $\left(\mathrm{Al}_{1-\mathrm{x}} \mathrm{Cr}_{\mathrm{x}}\right)_{2} \mathrm{O}_{3}$, where alumina is a protective layer against corrosion. The mentioned layers were verified by X-Ray Diffraction (XRD), that information were reported on this investigation and other researching works $(5,17,21,23)$. The above oxides are protectives and adherents, in- 
creasing the oxidation resistance. The second zone is composed of about $60 \%$ of iron, $25 \%$ of chromium, $8 \%$ of nickel, $6 \%$ of silicon and $1 \%$ of oxygen, according to EDAX analysis. These elements form Fe3Al, AlNi y $\mathrm{Cr} 1.36 \mathrm{Fe} 0.52$ with phase zones of AlNi and others white zones composed of $\mathrm{Cr} 12 \mathrm{Fe} 32 \mathrm{Mo} 7 \mathrm{Ni7}$, besides they have some black porous, which are formed by inter-diffusion of chromium, nickel and iron outward, as well as the aluminum inward substrate (causing Kirkendall effect). The third zone corresponds at substrate, which has little zones rich in chromium, nickel and molybdenum. In this figure is observed the continuity of both, coating and substrate, even after 1000 oxidation hours, which infers good adhesion between the two phases, besides on the inter-phase porous and empties are not observed.
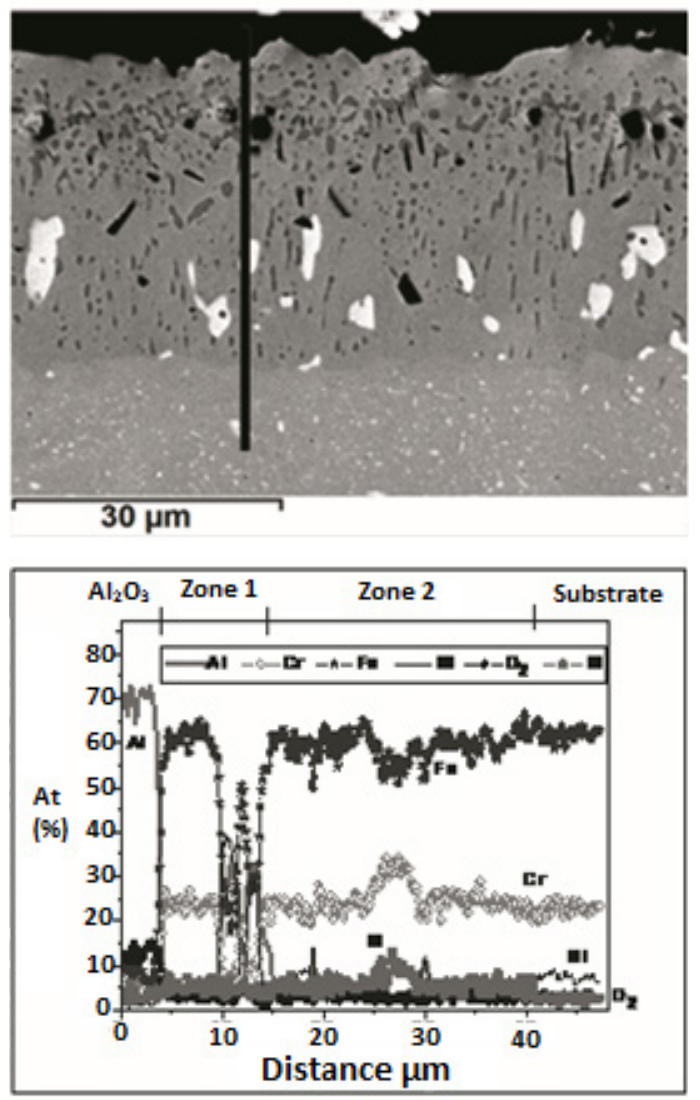

Figure 2. Cross section of Al-Si coating on stainless steels AISI 316 and oxidized in water vapor at $750^{\circ} \mathrm{C}$ during 1000 hours.

In figure 3 is observed the sweep image on contrast phase carried out by an AFM, in this figure is appreciably the topography of Al-Si/AISI 316 a cross section sample (oxidized at $750^{\circ} \mathrm{C}$ for 400 h). This figure shows a color-scheme changing from left (coating) to right (substrate). In addition, on the image can also be noted the voltage gradient, which is generated after Contrast phase sweep mode. It is appreciated on the substrate, the homogeneity of voltage peaks, as opposed to the coating zone, where the voltage signal decrease significantly. It is important to appreciate some voltages peak are higher than others on the substrate zone, and probably they are generated by aluminum inter-diffusion.

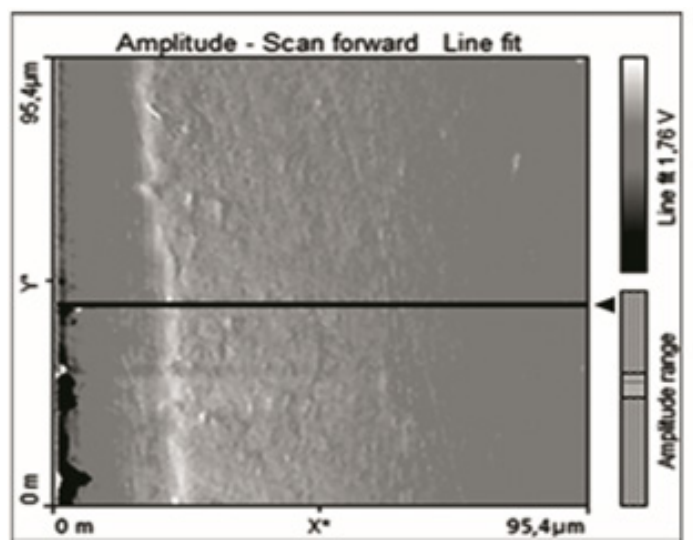

a. Contrast phase AFM sweep

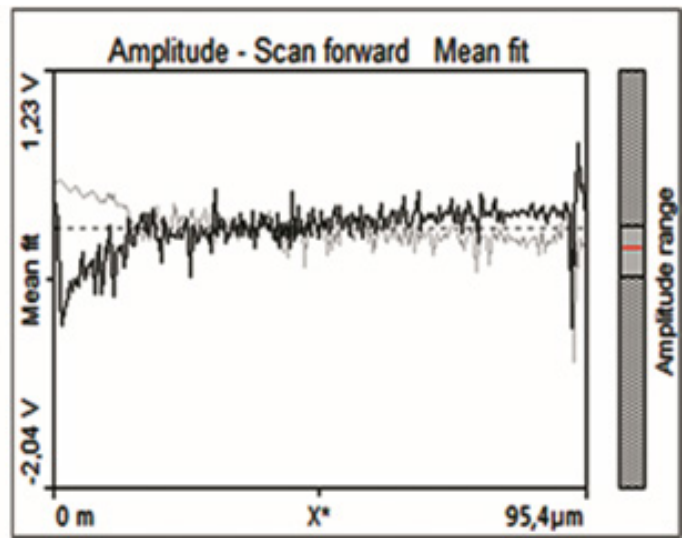

b. Voltage gradient in AFM contrast phase

Figure 3. Cross-section of Al-Si coating with TT, after to be oxidized in water vapor loop at $750^{\circ} \mathrm{C}$ for 400 hours

The figure 4 shows the topography and voltage amplitude by contrast mode AFM sweep. In this figure, 
the highest voltage peaks are light color and dark tones are the lowest. The C-S inter-phase shows the highest voltages peaks, decreasing into substrate. On the substrate, the voltage peaks are more homogeneity with an average values of $153.75 \mathrm{mV}$; reporting some higher peaks $(307.5 \mathrm{mV})$ produced by aluminum inter-diffusion on the C-S interphase. This analysis gives visual information about the voltages behavior between sample and AFM cantilever during cross section sweep, notifying relevant information, which can be related with nano-hardness of sample ${ }^{(25,26)}$.

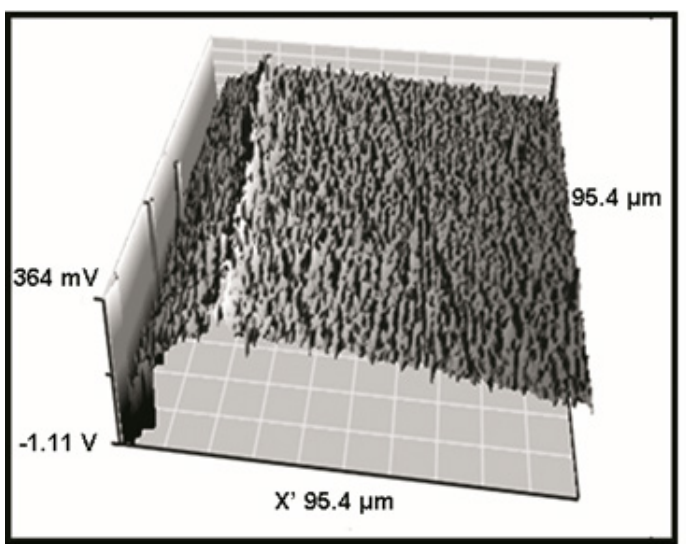

Figure 4. Differential voltage on cross-section of Al-Si coating with TT, after to be oxidized in a water vapor loop at $750^{\circ} \mathrm{C}$ for 400 hours

Finally, nano-indentation tests were carried out, which were in accordance with Vickers micro-hardness results, as well as with AFM voltage gradient. The nano-indentation tests reported variable hardness behavior (see figure 5), obtaining a maximum value of $11.4 \mathrm{GPa}$, on $23 \mu \mathrm{m}$ on the surface sample (external sample side), whose length coincide with the AFM sweeps on the C-S interphase, where highest voltage peaks were reported. Advancing on coating into surface direction, hardness decreases along of $10 \mu \mathrm{m}$ and increases of up to $8.5 \mathrm{GPa}$, and lastly start the final falling to the coating limit (5.5 $\mathrm{GPa}$ approximately), losing superficial homogeneity. Also, nano-indentation tests show hardness reduction as measures advances into the substrate, finally reaching a nano-hardness value between 6 and $7 \mathrm{GPa}$, which is greater 3 or $4 \mathrm{GPa}$ than the typically ranges reported for the study steel ${ }^{(24,25)}$. The above hardness reduction is almost gradual, but there is a fluctuation between 24 and $27 \mu \mathrm{m}$ due to the formation of intermetallics by the aluminum diffusion into the substrate and the chromium-nickel diffusion into the coating; this phenomenon is appreciate in the AFM and SEM tests too.

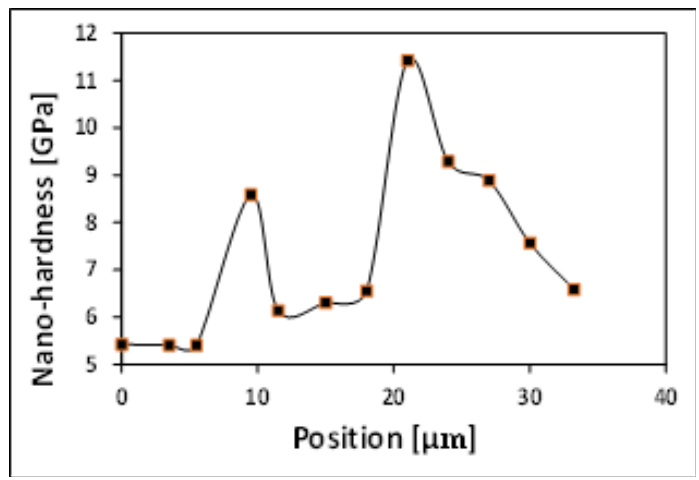

Figure 5. Nano-hardness profile of AISI 316 coated with Al-Si

Young's modulus presents a similar behavior in comparison with nano-hardness, specifically on the $\mathrm{C}-\mathrm{S}$ interphase, whose maximum value was $287 \mathrm{GPa}$. Advancing into the substrate, the modulus decreases reaching values up $250 \mathrm{GPa}$, a close value to the typically reported by other researchers for AISI 316 (200-240 GPa) ${ }^{(23,24)}$; this difference is due to aluminum inter-diffusion after the thermal treatment. In respect to the coating zone, the Young's modulus has a stable behavior, around $245 \mathrm{GPa}$ and not present an important increasing in relation to the substrate. Previous works help to conclude that the aluminum coating deposited by CVD-FBR reported better results about mechanical properties, in comparison with aluminum-silicon coatings ${ }^{(26)}$.

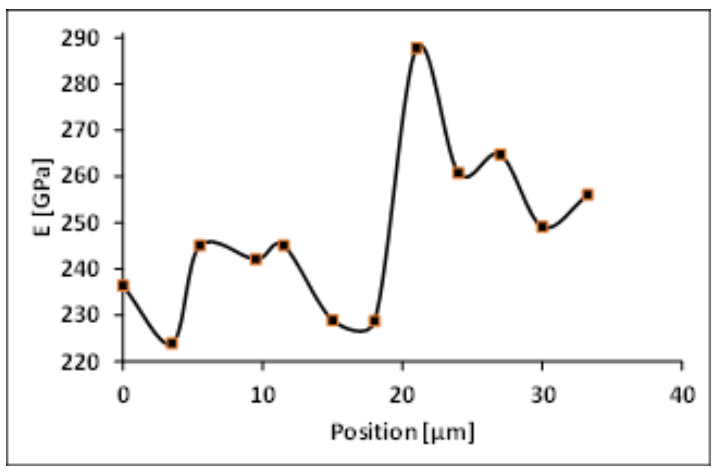

Figure 6. Young's modulus profile for AISI 316 coated with Al-Si 


\section{Conclusions}

- The obtained images by SEM and AFM showed good continuity between the substrate and the aluminum-silicon coating, due to there is not separation between them.

- The Vickers micro-hardness and nano-hardness tests showed a hardness increase of coating in respect to the substrate, confirming a significant improve on the substrate hardness thanks to the Al-Si coating application under evaluation conditions; which is in accordance with the AFM studies. Even though, AFM technique does not give quantitative values of hardness changes on the sample surface, it gives qualitative values.

- The Al-Si coating deposited by CVD-FBR can increase the resistance against water vapor on the substrate up to 100 times (improve of $25 \%$ ), front aluminum coating deposited by the same technique ${ }^{(17,26)}$. That is the reason why the mechanical properties were evaluated, the mechanical tests reported significantly improvements and it projects a good coatings performance on servic.

- The possible relation between voltage peaks reported by AFM sweeps (contrast phase mode) and nano-indentations results are showed. This possible relation drives the future studies to focus in to find their bond.

\section{References}

1. Marulanda JL, Castañeda SI, Remolina A. Recubrimientos depositados por CVD-FBR para protección a alta temperatura. Dyna. 2013; 80 (181). pp. 181-91.

2. Rodriguez P, Caussat B, Ablitzer C, Iltis X, Brothier M. Fluidization and coating of very dense powders by Fluidized Bed Chemical Vapour Deposition, Chemical Engineering Research and Design. 2013; 91. pp. 2477-2483.

3. Marulanda JL., Tristancho JL, Gonzáles HA. La tecnología de recuperación y protección contra el desgaste está en el rociado térmico. Prospectiva. 2014; 12, (1), pp. 70-78.
4. Castañeda SI, Bolívar FJ, y Pérez FJ Oxid Met (2010) 74: 61. https://doi.org/10.1007/ s11085-010-9200-z

5. Marulanda JL, Pérez FJ, Remolina A. Recubrimientos de aluminio-silicio realizados por deposición química de vapor en lecho fluidizado sobre el acero inoxidable AISI 316, Rev. Fac. ing.univ.Antioquia. 2013; 22 (34). pp. 63-70

6. Anastassiou C, Christoglou C, Angelopoulos G. Formation of aluminide coatings on $\mathrm{Ni}$ and austenitic 316 stainless steel by a low temperature FBCVD process. Surface \& Coatings Technology. 2010; 204, pp. 2240-2245

7. Marulanda JL, Pérez FJ, Castañeda SI. Behavior of aluminum coating by CVD-FBR in vapor oxidation at $700{ }^{\circ} \mathrm{C}$. Ciencia, Tecnología y Futuro. 2014; 5(4), pp. 77-86.

8. Fisher AC. Nanoindentation, Mechanical Engineering Series, New York, editorial Springer. 2012

9. Destouches B. Estudio del efecto del tamaño en nanoindentación. [Tesis Maestría]. [Cataluña]: Universidad Politécnica de Cataluña. Cataluña. España. (2008).

10. Lucchini R. Nanoindentación de capas finas de ZrW. [Tesis Maestría][ Cataluña]: Universidad Politécnica de Catalunya. Cataluña. España. (2009).

11. Gómez B, Maryory A. Caracterización de las propiedades Tribológicas de los recubrimientos Duros. [Tesis Doctorado][Barcelona]: Universidad de Barcelona. Barcelona. España (2005).

12. Lima FD, Kleinberg, MN, Arruda, HF, Costa FN, Valente MM, de Albuquerque VH, Rebouças, PP. A novel Vickers hardness measurement technique based on Adaptive Bal $\neg$ loon Active Contour. Method. Expert systems with applications. $2016 \mathrm{Vol}$ 45. pp. 294-306

13. Jayanthi N, Thamizharasan K. Vickers Microindentation Hardness Studies of DL-methionine Doped Copper Sulphate (MCS) single cristal. Materials Today: Proceedings. 2017 Vol. 4. pp. 358-362.

14. Qianhua K, Wenyi Y, Guozheng K, Qingping, S. Oliver-Pharr indenta $\neg$ tion method in de- 
termining elastic moduli of shape memory alloys. Journal of the mechanics and physics of solids. 2013 Vol 61. pp. 2015-2033.

15. Bhattacharya M, Dey A, Mukhopadhyay A. Influence of loading rate on nanohardness of sapphire. Ceramics International. 2016; Vol. 42. Pp. 13378-13386.

16. Page TF, Oliver WC, Mchargue CJ. The deformation-behavior of ceramic crystals subjected to very low load (nano) indentations. 2014; Vol. 7. pp. 450-473.

17. Marulanda JL, Alucema O, Barón, JA. Oxidación en vapor de agua de agua del acero inoxidable AISI 316 recubierto con $\mathrm{Al}$-Si por deposición química de vapor en lecho fluidizado.

18. AG. Nanosurf Easyscan 2 AFM Operating instructions version 1.3, Switzerland Prod. BT02089. Septiembre de 2008. Sitio web: http://www.virlab.virginia.edu/nanoscience clas/labs/materials/easyScan $\% 202 \% 20 \% 20$ AFM\%20Manual.pdf.

19. Fisher, C., Anthony, C. (2009). The IBIS Handbook of Nanoindentation, Fischer-Cripps Laboratories Pty Ltd.

20. Mesa L. Resultados de ensayos de nanoindentación. Laboratorio de Materiales y Minerales de la Universidad Nacional De Colombia. (2013). Medellín. Colombia.

21. Kan Q, Yan W, Kang G, Su Q. Oliver-Pharr indentation method in determining elastic moduli of shape memory alloys - A phase transformable material. Journal PF the Mechanics and Physics of Solids. 2013; 61(10). pp. 2015-2033

22. Marulanda JL, Castañeda SI, Pérez FJ. Improvement in Resistance to Vapor Oxidation of Aluminide-Coated AISI 304 and AISI 316 Steel Produced by Chemical Vapor Deposition in a Fluidized Bed Reactor; Oxidation of Metals. 2015; 84(3). pp. 429-445

23. Marulanda JL, Castañeda SI, Pérez, FJ. Aluminum coating by fluidized bed chemical vapor deposition on austenitic stainless steels AISI 304 and AISI 316. Dyna. 2015; 82 (189). pp. 22-29.

24. Roa JJ, Fargas G, MA, Jiménez P. Dependence of nanoindentation hardness with crystallographic orientation of austenite grains in metastable stainless steel. Materials Science and engineering: 2015 A. Vol. 645. pp 188-195

25. Jiménez P, Anglada E, Pellice SA, Cavalieri AL. Mechanical characterization of nano-reinforced silica based sol-gel hybrid coatings on AISI 316L stainless steel using nanoindentation techniques. Surface and Coatings Technology. 2009; Vol. 203. Issues 20-21. pp. 3325-3331.

26. Pérez D, Marulanda JL, Meza JM. Caracterización mecánica de recubrimientos de aluminio por CVD-FBR sobre aceros inoxidables y resistencia a la oxidación en vapor de agua. Revista Facultad de Ingeniería. 2015; 24 (40). pp. 9-16.

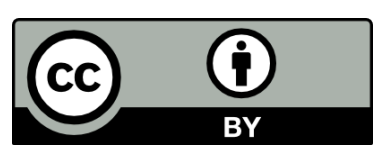

Revista Ingeniería y Competitividad por Universidad del Valle se encuentra bajo una licencia Creative Commons Reconocimiento - Debe reconocer adecuadamente la autoría, proporcionar un enlace a la licencia e indicar si se han realizado cambios. Puede hacerlo de cualquier manera razonable, pero no de una manera que sugiera que tiene el apoyo del licenciador o lo recibe por el uso que hace. 